\title{
HUBUNGAN PENDIDIKAN IBU DAN PARITAS DENGAN PEMILIHAN KONTRASEPSI SUNTIK
}

\author{
Ria Gustirini ${ }^{1}$ \\ ${ }^{1}$ Program Studi DIII Kebidanan, Institut Ilmu Kesehatan dan Teknologi Muhammadiyah \\ Palembang, Indonesia
}

\begin{tabular}{ll}
\hline Info Artikel & Abstrak \\
\hline Genesis Naskah: & Masalah kependudukan dewasa ini merupakan masalah penting yan mendapat \\
Submissions: 29-10-2020 & perhatian dan pembahasan yang serius dari ahli kependudukan baik di Indonesia \\
Revised: $8-11-2020$ & maupun diseluruh dunia. Salah satu hal yangdiduga sebagai penyebab \\
Accepted: 10-11-2020 & pertumbuhan penduduk berlebihan adalah angka kelahiran yang meningkat, hal ini \\
& menunjukkan bahwa kuantitas penduduk Indonesia merupakan permasalahan \\
& strategis. Program Keluarga Berencana (KB) memiliki paradigma baru yang telah \\
& diubah visinya dari mewujudkan Norma Keluarga Kecil Bahagia Sejahtera \\
& menjadi visi untuk mewujudkan keluarga yang berkualitas. Tingginya tingkat \\
Kenggunaan kontrasepsi suntik dibandingkan dengan jenis kontasepsi lainnya & menyebabkan penggunaan alat kontrasepsi lain seperti kurang diminati, pendidikan \\
Kontrasepsi suntik Paritas & ibu dan paritas merupakan salah satu faktor yang berperan dalam pemilihan \\
Pendidikan & kontrasepsi. Penelitian ini bertujuan untuk mengetahui hubungan pendidikan ibu \\
& dan paritas dengan penggunaan kontrasepsi suntik. Penelitian menggunakan \\
& pendekatan analitik kuantitatif dengan desain penelitian cross sectional. Populasi \\
& pada penelitian ini adalah seluruh akseptor KB baru di Puskesmas Plaju \\
& Palembang Tahun 2011 sedangkan sampel penelitian ini adalah sebagian akseptor \\
& KB baru di Puskesmas Plaju Palembang. Besar sampel penelitian menggunakan \\
& rumus slovin sehingga didapat sebanyak 379 responden. Sampel ditentukan dengan \\
& menggunakan teknik simple random sampling. Uji statistik yang digunakan adalah \\
uji chi-Square. Hasil penelitian menunjukkan terdapat hubungan yang bermakna & antara pendidikan ibu dan paritas dengan penggunaan kontrasepsi suntik (p<0,05). \\
& Peran aktif tenaga kesehatan khususnya bidan sebagai tenaga profesional sangat \\
diperlukan dalam memberikan konseling, informasi dan edukasi tentang KB & sehingga ibu mendapatkan informasi yang lengkap terkait jenis, keuntungan, dan \\
efek samping dari masing-masing alat kontrasepsi dan dapat memilih alat \\
kontrasepsi yang sesuai dengan kondisi kesehatan dan karakteristik ibu.
\end{tabular}

\section{MOTHER EDUCATION AND PARITY RELATED WITH THE SELECTION OF CONTRACEPTIVE INJECTION}

\section{Keywords: \\ Contraceptive injection, \\ Education, Parity}

\begin{abstract}
Today's population problem is an important issue that has received serious attention and discussion from population experts both in Indonesia and around the world. One of the things that is suspected of causing excessive population growth is the increasing birth rate, this shows that the quantity of Indonesia's population is a strategic issue. The Family Planning Program has a new paradigm which has changed its vision from realizing Happy and Prosperous Small Family Norms to a vision of realizing a quality family. The high rate of injection contraceptive use compared to other types of contraception causes the use of other contraceptives such as less interest, maternal education and parity are factors that play a role in contraceptive selection. This study aims to determine the relationship between maternal education and parity with injection contraceptive use. This study used a
\end{abstract}


quantitative analytic approach with a cross sectional study design. The population in this study were all new family planning acceptors at Puskesmas Plaju Palembang in 2011 while the sample of this study were some of the new family planning acceptors at Puskesmas Plaju Palembang. The sample size of the study used the slovin formula to obtain 379 respondents. The sample is determined using simple random sampling technique. The statistical test used is the chi-square test.The results showed that there was a significant relationship between maternal education and parity with injection contraceptive use $(p<0.05)$. The active role of health workers, especially midwives as professionals, is needed in providing counseling, information and education about family planning so that mothers get complete information regarding the types, benefits, and side effects of each contraceptive and can choose contraceptives according to health conditions. and mother characteristics.

\section{KorespondensiPenulis:}

Ria Gustirini

Jl. Jenderal A, Yani, 13 Ulu

Email: riagustirini@gmail.com

Journal of Midwifery Science and Women's Health 
Gustirini/JMSWH, Volume1, Nomor 1 tahun 2020: 1-7

\section{PENDAHULUAN}

Masalah kependudukan dewasa ini merupakan masalah penting yan mendapat perhatian dan pembahasan yang serius dari ahli kependudukan baik di Indonesia maupun diseluruh dunia. Indonesia merupakan salah satu negara dengan jumlah penduduk ke-empat terbesar di dunia setelah Cina, India, dan Amerika Serikat. Indonesia menyumbang sekitar 6\% penduduk di Asia (Ibrahim et al., 2019)

Indonesia menempati peringkat 110 dari 177 negara di seluruh dunia dalam hal indeks pembangunan manusia. Keadaan ini dikhawatirkan akan terus memburuk apabila jumlah penduduk terus meningkat secara tajam dan menyebabkan program pembangunan pemerintah tidak dapat dinikmati seluruh masyarakat yang ada. Salah satu hal yang diduga sebagai penyebab pertumbuhan penduduk berlebihan adalah angka kelahiran yang meningkat (Farahan, 2016).

Indonesia mengalami peningkatan laju pertumbuhan penduduk dari $1,45 \% \quad(1900$ sampai 2000) menjadi $1,49 \%$ (2000 sampai 2010). Berdasarkan sensus penduduk (SP) 2010, dalam periode 10 tahun (2000 sampai 2010) jumlah penduduk Indonesia meningkat sebanyak 32,5 juta jiwa, yaitu dari sebanyak 205,8 juta jiwa menjadi sebanyak 237,6 juta jiwa. Hal ini menunjukkan bahwa kuantitas penduduk Indonesia merupakan permasalahan strategis (Ibrahim et al., 2019).

Saat ini pertumbuhan penduduk Indonesia 1,6 persen per tahun. Suatu pertumbuhan yang cukup mengkhawatirkan, karena dari pertumbuhan ini masih dihasilkan sekitar 3-4 juta jiwa manusia baru di Indonesia per tahun. Program Keluarga Berencana (KB) memiliki paradigma baru yang telah diubah visinya dari mewujudkan Norma Keluarga Kecil Bahagia Sejahtera menjadi visi untuk mewujudkan keluarga yang berkualitas tahun 2015 (Putriningrum, 2012).

Di Sumatera Selatan, berdasarkan data yang dihimpun dari BKB-PP tahun 2009, jumlah Pasangan Usia Subur (PUS) sebesar 251. 957 peserta, dengan peserta KB suntik sebesar $27.616(39.5 \%)$, pil sebesar 23. 973 $(34,3 \%)$, MOP sebesar $6.987(4.1 \%)$ MOW sebesar 6.486 (4\%), IUD sebesar $1.447(1 \%)$, implant sebesar 3.291(2\%). Berdasarkan data tersebut, kontrasepsi yang paling banyak digunakan adalah jenis kontrasepsi suntik (Sumsel, 2009).

Journal of Midwifery Science and Women's Health Volume 1, Nomor 1 Tahun 2020
Banyak faktor yang mempengaruhi seseorang untuk memilih alat kontrasepsi yang ingin digunakan. Pendidikan merupakan salah satu faktor yang mempengaruhi persepsi seseorang untuk menerima ide-ide baru. Semakin tinggi tingkat pendidikan seseorang akan semakin mudah untuk menerima gagasan program KB. (Hanna, 2012) Penelitian ini didukung oleh penelitian sebelumnya dimana pendidikan memiliki hubungan yang bermakna dengan pemilihan kontrasepsi (Lontaan and Kusmiyati, 2014).

Paritas adalah jumlah anak hidup yang dimiliki akseptor KB. Jumlah anak mempunyai kaitan erat dengan program keluarga berencana karena dengan mengetahui jumlah anak akseptor dapat diketahui pula tercapainya sasaran program keluarga berencana, selain itu juga berpengaruh terhadap tingkat kelangsungan penggunaan alat kontrasepsi. Pada umumnya semakin besar jumlah anak yang dimiliki kelangsungan penggunaan alat kontrasepsi akan semakin tinggi, hal ini karena jumlah anak yang diinginkan sudah tercapai (Hanna, 2012). Berdasarkan penelitian sebelumnya terdapat hubungan yang bermakna antara jumlah anak dengan penggunaan metode kontrasepsi (Yeni et al., 2017).

Tingginya tingkat penggunaan kontrasepsi suntik dibandingkan dengan jenis kontasepsi lainnya menyebabkan penggunaan alat kontrasepsi lain seperti kurang diminati. Penelitian ini bertujuan untuk mengetahui hubungan pendidikan ibu dan paritas dengan penggunaan kontrasepsi suntik.

\section{METODE}

Penelitian menggunakan pendekatan analitik kuantitatif dengan desain penelitian cross sectional. Populasi pada penelitian ini adalah seluruh akseptor KB baru di Puskesmas Plaju Palembang Tahun 2011 sedangkan sampel penelitian ini adalah sebagian akseptor KB baru di Puskesmas Plaju Palembang. Besar sampel penelitian menggunakan rumus slovin sehingga didapat sebanyak 379 responden. Sampel ditentukan dengan menggunakan tehnik simple random sampling dengan cara lotere yaitu memberi nomor urut pada semua data populasi, kemudian mengundi nomor urut sebagai sampel yang akan diteliti. 
Analisis data yang dilakukan meliputi analisis univariat dan bivariat. Analisis yang digunakan untuk melihat Hubungan antara variabel independen (Pendidikan dan paritas) dengan variabel dependen (pemakaian KB suntik). Analisis bivariat bertujuan untuk melihat hubungan antara variabel independen (pendidikan dan paritas) dan variabel dependen (penggunaan kontrasepsi suntik). Uji statistik yang digunakan adalah uji chi-Square.

\section{HASIL}

\section{Analisis Univariat}

Analisis univariat dilakukan terhadap tiap variabel hasil penelitian yaitu variabel independen (pendidikan ibu, dan paritas) dan variabel dependen (pemakaian KB suntik) dianalisis dengan menggunakan tabel distribusi frekuensi

Tabel 1 Distribusi Frekuensi Responden Berdasarkan Pendidikan

\begin{tabular}{lcc}
\hline Pendidikan Ibu & Frekuensi (f) & Presentase(\%) \\
\hline Tinggi & 152 & 40,1 \\
Rendah & 227 & 59,9 \\
\hline Jumlah & 379 & 100
\end{tabular}

Sumber: Data riset, 2012

Tabel 1 menunjukkan bahwa responden berpendidikan rendah lebih banyak dengan jumlah 227 responden (59,9\%) dibandingkan dengan responden yang berpendidikan tinggi dengan jumlah 152 responden $(40,1 \%)$.

Tabel 2 Distribusi Frekuensi Responden Berdasarkan Paritas

\begin{tabular}{lll}
\hline Paritas & Frekuensi (f) & Presentase(\%) \\
\hline Tinggi & 214 & 56,5 \\
Rendah & 165 & 43,5 \\
\hline Jumlah & 379 & 100 \\
\hline
\end{tabular}

Sumber: Data riset,2012

Tabel 2 menunjukkan bahwa responden dengan paritas tinggi lebih banyak dengan jumlah 214 responden $(56,5 \%)$ dibandingkan dengan responden dengan paritas rendah dengan jumlah 165 responden $(43,5 \%)$.

\section{Analisis Bivariat}

Tabel 3 Hubungan Pendidikan Ibu akseptor KB dengan pemilihan kontrasepsi suntik

\begin{tabular}{|c|c|c|c|c|c|c|c|}
\hline \multirow{3}{*}{$\begin{array}{l}\text { Pendi- } \\
\text { dikan }\end{array}$} & \multicolumn{4}{|c|}{ Pemilihan KB } & \multirow{3}{*}{$\mathrm{n}$} & \multirow{3}{*}{$\%$} & \multirow{3}{*}{$\begin{array}{c}p \\
\text { value }\end{array}$} \\
\hline & \multicolumn{2}{|c|}{ Suntik } & \multicolumn{2}{|c|}{ Non Suntik } & & & \\
\hline & $\mathrm{n}$ & $\%$ & $\mathrm{n}$ & $\%$ & & & \\
\hline Tinggi & 90 & 59,2 & 62 & 40,8 & 152 & 100 & \\
\hline Rendah & 161 & 70,9 & 66 & 29,1 & 227 & 100 & 0,024 \\
\hline Jumlah & 251 & 66,2 & 128 & 33,8 & 379 & 100 & \\
\hline
\end{tabular}

Tabel 3 menunjukkan bahwa responden yang berpendidikan rendah (70,9\%), lebih banyak menggunakan kontrasepsi suntik dibandingkan dengan responden yang berpendidikan tinggi $(59,2 \%)$. Hasil uji Chi Square didapatkan nilai $p$ value $=$ $0,024(\mathrm{p}<0,05)$ sehingga terdapat hubungan antara pendidikan ibu dengan penggunaan kontrasepsi suntik.

Tabel 4 Hubungan Paritas dengan Penggunaan Kontrasepsi Suntik

\begin{tabular}{ccccccccc}
\hline \multirow{2}{*}{ Paritas } & \multicolumn{9}{c}{ Pemilihan KB } & & & P \\
\cline { 2 - 5 } & \multicolumn{2}{c}{ Suntik } & \multicolumn{2}{c}{ Non suntik } & & $\%$ & Value \\
\cline { 2 - 5 } & $\mathrm{n}$ & $\%$ & $\mathrm{n}$ & $\%$ & & & \\
\hline Tinggi & 153 & 71,5 & 61 & 28,5 & 214 & 100 & \\
Rendah & 98 & 59,4 & 67 & 40,6 & 165 & 100 & \multirow{2}{*}{0,018} \\
\hline Jumlah & 251 & 66,2 & 128 & 33,8 & 379 & & \\
\hline
\end{tabular}

Sumber: Data riset, 2012

Tabel 4 menunjukkan bahwa responden dengan paritas tinggi lebih banyak menggunakan kontrasepsi suntik $(71,5)$ dibandingkan dengan responden dengan paritas rendah $(59,4 \%)$. Dari hasil uji Chi Square didapatkan nilai $p$ value $=0,018(\mathrm{p}<$ 0,05 ) sehingga terdapat hubungan antara paritas dengan penggunaan kontrasepsi suntik.

\section{PEMBAHASAN}

Salah satu cara yang digunakan untuk menekan laju pertumbuhan penduduk adalah melalui pengendalian angka kelahiran. Keluarga Berencana (KB) adalah salah satu pelayanan kesehatan yang bertujuan membantu pasangan suami istri untuk melahirkan pada usia yang ideal, memiliki jumlah anak yang ideal, dan mengatur jarak kelahiran anak yang 
Gustirini/JMSWH, Volume1, Nomor 1 tahun 2020: 1-7

ideal dengan menggunakan cara, alat, dan obat kontrasepsi (Rizali et al., 2016).

Data badan kependudukan dan Keluarga Berencana Nasional (BKKBN) menunjukkan bahwa pada tahun 2013 ada 8.500.247 Pasangan Usia Subur (PUS) yang merupakan peserta KB baru dan hampir separuhnya menggunakan metode kontrasepsi suntik (RI, 2014).

Berdasarkan data tahun 2009, jumlah Pasangan Usia Subur (PUS) di Sumatera Selatan sebesar 251. 957 peserta, dengan peserta KB suntik sebesar 27.616 (39.5\%), pil sebesar 23. 973 (34,3\%), MOP sebesar 6.987 (4.1\%) MOW sebesar 6.486 (4\%), IUD sebesar 1.447 (1\%), implant sebesar 3.291(2\%). Berdasarkan data tersebut, kontrasepsi yang paling banyak digunakan adalah jenis kontrasepsi suntik (Sumsel, 2009).

Menurut Dinas Kesehatan Kota Palembang tahun 2011, jurnlah peserta KB aktif di Kota Palembang sebanyak 156.986 orang dengan jenis kontrasepsi suntik merupakan jenis kontrasepsi yang paling banyak digunakan, yaitu sebanyak 75.114 orang dengan persentase sebesar 47,85\%. Dari 16 kecamatan yang ada, kecamatan Bukit Kecil merupakan salah satu kecamatan yang paling banyak menggunakan kontrasepsi suntik (Tjekyan, 2015).

Perkembangan beberapa tahun terakhir dapat disimpulkan bahwa trend Penggunaan kontrasepsi suntik masih menjadi pilihan terbanyak akseptor KB dibandingkan dengan metode kontrasepsi lainnya.

\section{A. Hubungan Antara Pendidikan Ibu dengan Penggunaan Kontrasepsi Suntik}

Pendidikan adalah usaha sadar untuk menyiapkan peserta didik melalui kegiatan bimbingan, pengajaran, dan atau latihan bagi peranannya masa yang akan datang. Dapat juga pendidikan diartikan sebagai proses memanusiakan manusia secara manusiawi, disesuaikan dengan perkembangan situasi dan kondisi sosial (Putriningrum, 2012).

Pendidikan merupakan faktor penting yang memengaruhi penggunaan kontrasepsi. Hasil analisis bivariat pada tabel 3 menunjukkan responden yang berpendidikan rendah memiliki hubungan yang bermakna dengan penggunaan kontrasepsi suntik $(p<0,05)$, hal ini dikarenakan kebanyakan dari akseptor KB memilih KB suntik karena mereka hanya perlu melakukannya 1-3 bulan sekali dan tidak perlu melalui proses trauma seperti pada saat pemasangan spiral. Kontrasepsi suntik dinilai efektif, pemakaiannya yang praktis, harganya relatif murah dan aman. Namun pendidikan rendah tidak secara mutlak memiliki pengetahuan kurang, karena saat ini pendidikan kesehatan tentang $\mathrm{KB}$ secara intensif diberikan oleh tenaga kesehatan (Septianingrum et al., 2018).

Hasil penelitian ini sesuai dengan penelitian yang dilakukan oleh Putriningrum dimana pendidikan merupakan salah satu faktor yang berpengaruh terhadap pemilihan kontrasepsi suntik, hal ini dikarenakan seseorang yang telah menerima pendidikan yang lebih baik atau lebih tinggi biasanya akan lebih mampu berfikir secara rasional, maka dia akan lebih mudah mendapatkan informasi (Putriningrum, 2012).

Penelitian ini juga sejalan dengan penelitian yang dilakukan oleh Muhammad Irwan Rizali dimana hasil penelitian terdapat hubungan yang bermakna antara pendidikan ibu dengan pemilihan metode kontrasepsi suntik. Semakin tinggi tingkat pendidikan akan jelas memengaruhi pribadi seseorang dalam berpendapat, berpikir, bersikap, lebih mandiri dan rasional dalam mengambil keputusan dan tindakan. Hal ini juga akan memengaruhi secara langsung seseorang dalam hal pengetahuannya akan orientasi hidupnya termasuk dalam merencanakan keluarganya (Rizali et al., 2016).

Peneliti berasumsi bahwa kontrasepsi suntik banyak diminati responden yang berpendidikan rendah dikarenakan kurangnya pengetahuan tentang kontrasepsi yang dipakai, sedangkan responden yang berpendidikan tinggi lebih memahami efek samping dari pemakaian kontrasepsi suntik.

\section{B. Hubungan Antara Paritas dengan Penggunaan Kontrasepsi Suntik}

Paritas adalah jumlah kehamilan yang menghasilkan janin hidup bukan jumlah janin yang dilahirkan. Janin yang lahir hidup atau mati setelah viabilitas dicapai, tidak mempengaruhi paritas (Bainuan, 2017). Seseorang yang berparitas lebih dari satu sudah seharusnya menjadi akseptor KB untuk mengatur atau menjarangkan kehamilannya, tetapi dewasa ini banyak akseptor KB yang masih mengalami kesulitan dalam menentukan pilihannya (Bahu et al., 2019). 
Umumnya semakin banyak jumlah anak, maka seorang wanita akan lebih cenderung menggunakan KB untuk membatasi jumlah anak, tetapi tidak menutup kemungkinan pula pada wanita yang memiliki jumlah anak di bawah 2 turut menggunakan KB dengan harapan dapat menunda kelahiran (Farahan, 2016).

Berdasarkan penelitian yang telah dilakukan didapatkan hubungan antara paritas dengan penggunaan kontrasepsi suntik $(p<0,05)$. Hal ini sejalan dengan penelitian yang dilakukan oleh Yeni dkk bahwa paritas merupakan faktor protektif dari perilaku penggunaan metode kontrasepsi (Yeni et al., 2017).

Penulis berasumsi bahwa tingginya penggunaan $\mathrm{KB}$ suntik pada multipara dikarenakan pengalaman ibu dalam menggunakan $\mathrm{KB}$ suntik sehingga ibu malas untuk mencoba metode $\mathrm{KB}$ lain. Hal ini dihubungkan dengan pengaruh pengalaman sendiri maupun orang lain terhadap pengetahuan yang dapat mempengaruhi perilaku saat ini atau kemudian, pengalaman yang diperoleh dapat memperluas pengetahuan seseorang (Bahu et al., 2019).

\section{KESIMPULAN}

Berdasarkan hasil penelitian dapat disimpulkan bahwa terdapat hubungan yang bermakna antara pendidikan ibu dan paritas dengan penggunaan kontrasepsi suntik.

Peran aktif tenaga kesehatan khususnya bidan sebagai tenaga profesional sangat diperlukan dalam memberikan konseling, informasi dan edukasi tentang KB sehingga ibu mendapatkan informasi yang lengkap terkait jenis, keuntungan, dan efek samping dari masing-masing alat kontrasepsi dan dapat memilih alat kontrasepsi yang sesuai dengan kondisi kesehatan dan karakteristik ibu.

\section{DAFTAR PUSTAKA}

Bahu, R., Hasania, E. \& Hilamuhu, F. 2019. Hubungan Paritas dan Dukungan Suami dengan Rendahnya Minat Penggunaan Alat Kontrasepsi Metode Tubektomi di Puskesmas Tibawa. Akademika, 8, 67-77.
Bainuan, L. D. 2017. Faktor Umur Dan Paritas Akseptor $\mathrm{Kb}$ Terhadap Pemilihan Kontrasepsi Suntik. Midwifery Journal of Akbid Griya Husada Surabaya, 4, 102-102.

Farahan, N. 2016. Gambaran Tingkat Pengetahuan Penggunaan Alat Kontrasepsi Pada Wanita Usia Subur Dan Dukungan Petugas Di Desa Bebandem Kabupaten Karangasem Bali Tahun 2014. E-Jurnal Medika, 5, 1-12.

Hanna, A. 2012. Hubungan Beberapa Faktor Akseptor dengan Pemilihan Alat Kontrasepsi Suntik pada Wanita Pus Keluarga PRA Ks dan Ks1 di Kelurahan Pongangan Triwulan I 2012. Jurnal Kesehatan Masyarakat Universitas Diponegoro, 1, 18751.

Ibrahim, W. W., Misar, Y. \& Zakaria, F. 2019. Hubungan Usia, Pendidikan Dan Paritas Dengan Penggunaan Akdr Di Puskesmas Doloduo Kabupaten Bolaang Mongondow. Akademika, 8, 35-44.

Lontaan, A. \& Kusmiyati, K. 2014. FaktorFaktor yang Berhubungan dengan Pemilihan Kontrasepsi Pasangan Usia Subur di Puskesmas Damau Kabupaten Talaud. JIDAN (Jurnal Ilmiah Bidan), 2, 27-32.

Putriningrum, R. 2012. Faktor-faktor yang mempengaruhi ibu dalam pemilihan kontrasepsi kb suntik di bps. Ruvina surakarta. Jurnal Kesehatan Kusuma Husada.

RI, K. K. 2014. INFODATIN " Situasi dan Analisis Keluarga Berencana.

Rizali, M. I., Ikhsan, M. \& Salmah, A. U. 2016. Faktor yang Berhubungan Dengan Pemilihan Metode Kontrasepsi Suntik di Kelurahan Mattoangin Kecamatan Mariso Kota Makassar. Media Kesehatan Masyarakat Indonesia, 9, 176-183.

Septianingrum, Y., Wardani, E. M. \& Kartini, Y. 2018. Faktor-Faktor yang Mempengaruhi Tingginya Akseptor KB Suntik 3 Bulan. Jurnal Ners dan Kebidanan (Journal of Ners and Midwifery), 5, 015-019. 
Gustirini/JMSWH, Volume1, Nomor 1 tahun 2020: 1-7

Sumsel, B.-P. P. 2009. Pembinaan Peserta KB Aktif.

Tjekyan, S. 2015. Karakteristik Demografi Akseptor Kontrasepsi Suntik Depot Medroxyprogesterone Acetate di Puskesmas Merdeka Palembang Periode Januari? Desember 2012. Majalah Kedokteran Sriwijaya, 47.

Yeni, Y., Mutahar, R., Etrawati, F. \& Utama, F. 2017. Paritas Dan Peran Serta Suami Dalam Pengambilan Keputusan Terhadap Penggunaan Metode Kontrasepsi. Media Kesehatan Masyarakat Indonesia Universitas Hasanuddin, 13, 362-368. 